\title{
Phenology and related traits for wheat adaptation
}

\author{
Jessica Hyles $\mathbb{D}^{1,2} \cdot$ Maxwell T. Bloomfield ${ }^{3} \cdot$ James R. Hunt ${ }^{3} \cdot$ Richard M. Trethowan $^{1} \cdot$ Ben Trevaskis $^{2}$
}

Received: 24 January 2020 / Revised: 6 May 2020 / Accepted: 6 May 2020 / Published online: 26 May 2020

(c) The Author(s) 2020. This article is published with open access

\begin{abstract}
Wheat is a major food crop, with around 765 million tonnes produced globally. The largest wheat producers include the European Union, China, India, Russia, United States, Canada, Pakistan, Australia, Ukraine and Argentina. Cultivation of wheat across such diverse global environments with variation in climate, biotic and abiotic stresses, requires cultivars adapted to a range of growing conditions. One intrinsic way that wheat achieves adaptation is through variation in phenology (seasonal timing of the lifecycle) and related traits (e.g., those affecting plant architecture). It is important to understand the genes that underlie this variation, and how they interact with each other, other traits and the growing environment. This review summarises the current understanding of phenology and developmental traits that adapt wheat to different environments. Examples are provided to illustrate how different combinations of alleles can facilitate breeding of wheat varieties with optimal crop performance for different growing regions or farming systems.
\end{abstract}

\section{Introduction}

Genes for phenology and plant development, their interactions with each other and the environment largely determine if a wheat (Triticum aestivum L.) crop is successful. For instance, in order to reach maximum seed size and number (potential yield), wheat must establish, develop biomass and flower at a time that coincides with optimal seasonal conditions (Trethowan 2014). Flowering in winter risks frost damage to reproductive structures, and suboptimal radiation levels can reduce yield (Dreccer et al. 2018). Alternatively, if crops flower too late in warm and dry environments, heat damage and water limitation can reduce yield (Flohr et al. 2017). Other aspects of plant biology beyond development are important for adaptation, including winter hardiness and

Associate Editor: Alison Bentley

Jessica Hyles

jessica.hyles@csiro.au

1 The Plant Breeding Institute, University of Sydney, 107 Cobbity Road, Cobbity, NSW 2750, Australia

2 CSIRO Agriculture and Food, GPO Box 1700, Canberra, ACT 2601, Australia

3 Department of Animal, Plant and Soil Sciences, La Trobe University, 5 Ring Road, Bundoora, VIC 3083, Australia plant architecture, and these must also be co-ordinated with seasonal development.

Understanding the genetic basis for variation in phenology and other adaptive traits can inform crop breeding strategies and contribute to prediction of yield risks, such as drought, frost or heat, and thereby improve crop management. This review focusses on the molecular genetics of wheat adaptation, and how this knowledge can facilitate breeding wheat adapted to diverse growing environments or different farming systems.

\section{Defining and measuring wheat development}

Development is the progression of the plant lifecycle, independent of growth that is due to accumulation of biomass. Development comprises distinct phases outlined in Fig. 1. Feekes developed a scale (stages 1-11) classifying the wheat lifecycle from tillering, stem elongation, heading and flowering, through to ripening (Fig. 1b.) Another developmental scale developed by Haun (1973) quantifies progressive leaf emergence on the main stem of wheat, which can then be used to determine leaf emergence rate, otherwise known as phyllochron. In addition, a comprehensive scale describing the wheat lifecycle from germination through to ripening in a two-digit computercompatible decimal format was developed (Zadoks et al. 1974). The "Zadoks scale" comprises 100 stages describing development of the wheat plant (Fig. 1c). 


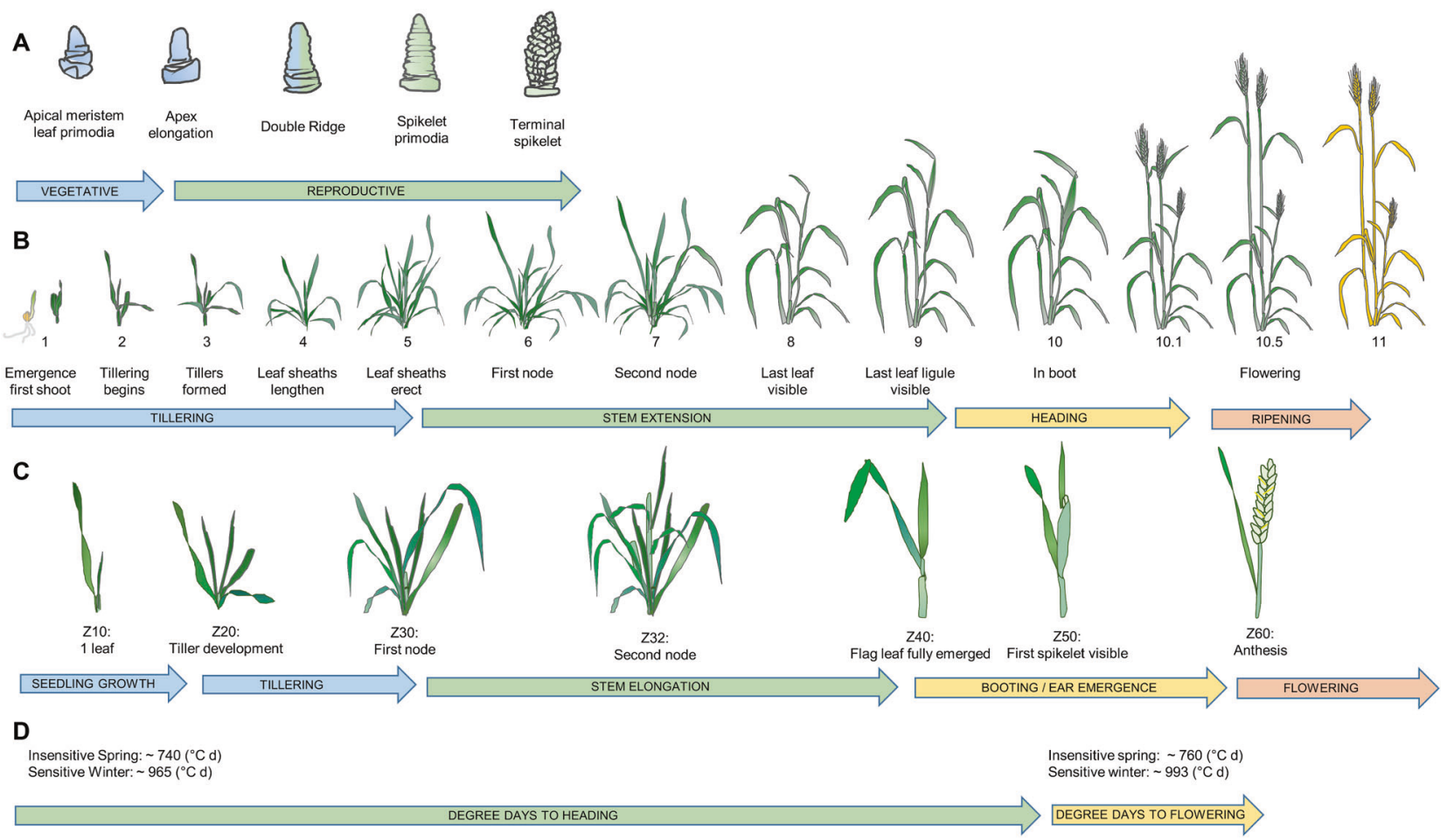

Fig. 1 Development stages in wheat. a Apex morphology, vegetative to reproductive (Moncur 1981). b Feekes Scale, stage 1-11 (Feekes 1941; Large 1954). c Zadoks Decimal Scale, score 0-100 (Zadoks et al. 1974). d Example of cumulative degree-days from emergence to

The wheat seed usually contains four leaf primordia, and more develop on the vegetative meristem during seedling growth (Z10-Z19). Leaf primordia appear as ridges on the apex, before elongation and differentiation into leaves. The position of emerging leaves is predictable with each new leaf developing on the opposing side of the apex to its predecessor. When around three non-embryonic leaves have developed, tiller buds located in the axils of leaves differentiate to produce tillers (branches) sequentially: tiller 1 from the axil of leaf 1, tiller 2 from leaf 2 and so on. Exceptions to this ordered leaf and tiller development have been described and may be environmentally dependent (Percival 1921). Each tiller has potential to produce secondary tillers. The overall extent of branching, tiller survival and fertility are affected by temperature, light, nutrient status and row spacing. Genetic control of tillering has also been identified (Hyles et al. 2017; Zhao et al. 2019). The primary stem continues to produce tillers, until the plant transitions to the stem elongation (reproductive) phase.

A pivotal point in the wheat lifecycle is transition of the shoot apex from vegetative to reproductive development (Fig. 1a, Waddington et al. 1983). At this stage, production of new leaf primordia ceases, and spikelet formation begins. This represents a commitment to flowering and determines the final leaf number (Wang et al. 1995). The shoot apex elongates, followed by formation of two ridges on the sides heading and emergence to flowering for near-isogenic lines (NIL)s with differing vernalisation or photoperiod requirements grown in inductive conditions (Bloomfield et al. 2018 and pers. comm.).

of the shoot apex, where previously only single ridges were formed. These can be visualised microscopically; when the plant has reached double-ridge stage, vegetative-toreproductive transition is complete (Slafer et al. 2015). The lower ridge is a leaf primordium that will later abort, while the upper ridge is the spikelet primordium that will differentiate to form all the floret organs: glume, lemma, palea and stamens of the floret (Moncur 1981). Subsequently, the terminal spikelet forms, and thereafter no further spikelets are formed on the primary axis. The duration of development from double ridge to the terminal spikelet stage is the primary determinant of maximum spikelet number (Rawson 1970).

Simultaneous to early stages of reproductive shoot apex development, stem elongation proceeds. Nodes formed during vegetative development thicken and become a point of rapid growth and extension to form internodes, with each successive internode longer than its predecessor (Evans 1975). This provides a means for the developing spike to travel upwards through the stem from Z30 onwards. As the stem elongates, spikelet differentiation and floret development also occur. Wheat adjusts its growth in response to environmental stress so that the last-formed spikelets at the base and tip are the first to abort in poor-growing conditions. Usually up to 12 floret primordia are formed in each spikelet; however, only 3-5 survive and set seed, thought to 
be a function of the competition for resources between spikes and stems during the elongation phase (Kirby 1988).

Synchrony of each developmental phase with optimal seasonal conditions is necessary to optimise production of biomass and yield. For instance, grain number and thus yield in wheat is largely determined by growth rates during the critical period that extends from emergence of the penultimate leaf until early grain filling (Dreccer et al. 2018). Agronomically, it is thus vital to align this sensitive stage to the likely occurrence of seasonal conditions (temperature, radiation and water availability) most conducive to wheat growth. The timing of developmental phases also influences abiotic stress tolerance such as winter hardiness. Seasonal conditions and regional factors, including available moisture, temperature, latitude and day length, all influence the duration of developmental phases (Slafer and Rawson 1994; Angus and Moncur 1977; Amir and Sinclair 1991; Trethowan et al. 2006). This dependence of crop phasic development upon the growing environment represents a strong genotype by environment interaction, and acts to synchronise the lifecycle with external conditions.

Early studies demonstrated that the switch from vegetative to reproductive development is promoted by prolonged cold temperatures of winter (vernalisation) (Chouard 1960). The duration of cold is important, for instance, a plant that responds by flowering after a "cold snap" in autumn would not survive in climates with long, cold winters. From a developmental perspective, vernalisation influences the duration of the vegetative phase, and is a large determinant of the final leaf number. Vernalisation requirement is typically combined with day-length-responsive flowering, such that plants that have vernalised over winter will flower rapidly as days subsequently lengthen in spring (Chouard 1960). This led to the "long-day" and "winter-type", classification of wheat. That is, the naturally occurring ancestral plant type (wild type) requires vernalisation followed by increasing photoperiod in order to flower. In regions with cold winters, autumn sowing of these types allows flowering to coincide with favourable temperatures and radiation in early summer for optimum yield.

\section{Interaction of plant development and the environment}

Alternative life-cycle strategies facilitate adaptation to different environments (Evans et al. 1975). Unlike winter types, spring wheats require little-to-no environmental inducement for flowering (Chouard 1960). These types typically flower rapidly without vernalisation, with rapid progression to the double-ridge stage, and reduced final leaf number relative to winter wheat in similar growing conditions. Spring wheat can also have varying levels of sensitivity to day length. Day-length-insensitive spring cultivars can progress to the terminal spikelet stage and flower rapidly even in short days. Taken together, the absence of vernalisation or day-length requirements allows some spring wheats to be sown in environments with milder winters and at different times of the year (see "Quantitative traits in the farming system", Fig. 3). From a study of wild emmer wheat Triticum dicoccoides, it is thought that spring types evolved from wild-type winter habit in the progenitor of cultivated hexaploid wheat (Kato et al. 1997).

Since wheat can be grown across diverse environments and at different times of the year, it is useful to calibrate development versus temperature and day length using accumulated thermal time or degree-days (DD), or photodegree days (PDD). This allows comparison of developmental rates across different conditions, where the rate of development per se differs. For DD (Eq. 1), calculations are based on accumulated temperature above a base, and may also consider an upper limit so that only temperatures conducive to plant development are considered. DD can be determined by summing daily average temperatures as the equation below, or considers more frequent measures of temperature or estimates thereof, for example, using sine curve or triangular equations (McMaster and Wilhelm 1997; Zalom et al. 1983; Snyder 1985).

$D D($ ave $)=\left[\frac{\text { Tmax }- \text { Tmin }}{2}\right]-$ Tbase.

Equation 1. Estimation of thermal time

$D D($ ave $)=$ Degree-days, average calculation $\left({ }^{\circ} \mathrm{C} \mathrm{d}\right)$

Tmax $=$ Maximum daily temperature $\left({ }^{\circ} \mathrm{C}\right)$

Tmin $=$ Minimum daily temperature $\left({ }^{\circ} \mathrm{C}\right)$

Tbase $=$ Base temperature, typically $0^{\circ} \mathrm{C}$ or $5^{\circ} \mathrm{C}$, dependent on growth stage

In a study by Bloomfield et al. (2018), development of near-isogenic lines (NILs) was recorded (in DD) under inductive growth conditions; the approximate cumulative DDs to heading and flowering relative to other scales of development are shown in Fig. 1d (Bloomfield, pers. comm.). Comparison of slow-developing wheats (photoperiod-sensitive winter types) versus fast-developing wheats (photoperiod-insensitive spring types) illustrates the variation in response to temperature between these different classes.

To determine PDD, cumulative time from sunrise to civil twilight (day length) can be incorporated through the following equation (Wilsie 1962):

$P D D=D D \times t$.

Equation 2. Estimation of photo-thermal time

$P D D=$ Photo-degree days $\left({ }^{\circ} \mathrm{C} \mathrm{d} \mathrm{h}\right)$

$D D=$ Degree-days $\left({ }^{\circ} \mathrm{C} \mathrm{d}\right)$

$t=$ day-length $(\mathrm{h})$ 
A similar approach can be applied to calibrate temperature accumulation during vernalisation. Vernal days, the cumulative time in days until vernalisation saturation is reached (i.e., double-ridge stage reached), are determined by summing days from germination to development of the final leaf (Robertson et al. 1996). Porter and Gawith (1999) suggest that vernalisation occurs most rapidly at $4.9^{\circ} \mathrm{C}$, and requires temperatures between -1.3 and $15.7^{\circ} \mathrm{C}$.

\section{Molecular pathways of wheat development}

Since the phenology of wheat determines adaptation to different environments, an understanding of the genes underlying developmental variation is paramount. The major genes affecting wheat phenology (see Fig. 2) are those related to vernalisation requirement, photoperiod sensitivity and earliness per se, which is the duration of development until flowering, in conditions where vernalisation and photoperiod requirements are met.

\section{Vernalisation pathway}

The key component of vernalisation requirement of wheat is the VERNALIZATION1 (VRN1) locus, with a copy on the long arm of chromosome 5, in each of the A, B and D subgenomes. VRNI encodes an MIKC-type MADS box
(MINICHROMOSOME MAINTENANCE1/AGAMOUS/ DEFICIENS/SERUM RESPONSE FACTOR), with a conserved 60 amino-acid MADS box DNA- binding domain and three additional domains I (intervening), $\mathrm{K}$ (keratinlike) and a C-terminal domain. VRN1 is most like the APETALA1/FRUITFULL class (AP1/FUL) of MADS box genes of Arabidopsis thaliana. These genes play important roles in floral development in Arabidopsis, and can trigger early flowering when expressed at high levels (Mandel and Yanofsky 1995). Unlike the APl/FUL genes of Arabidopsis, transcription of VRNI increases with exposure to prolonged cold (Danyluk et al. 2003; Trevaskis et al. 2003; Yan et al. 2003). It seems that VRNI evolved from recruitment of the floral-promoting potential of AP1/FUL genes to provide a low-temperature-induced flowering switch. This role for APl/FUL-like genes is seemingly unique to the temperate grasses. VRN1 is expressed in both leaves and shoot apices of vernalised plants; accumulation of VRN1 transcripts in the shoot apex is associated with the switch to reproductive development, while transcription of $V R N 1$ in leaves facilitates the long-day flowering response after winter (Fig. 2).

The precise mechanism that mediates low-temperature induction of VRN1 is not known, but histone modifications appear to play a role. Epigenetic modification of chromatin by histone modification or methylation of DNA has been well studied and linked to heritable changes in gene
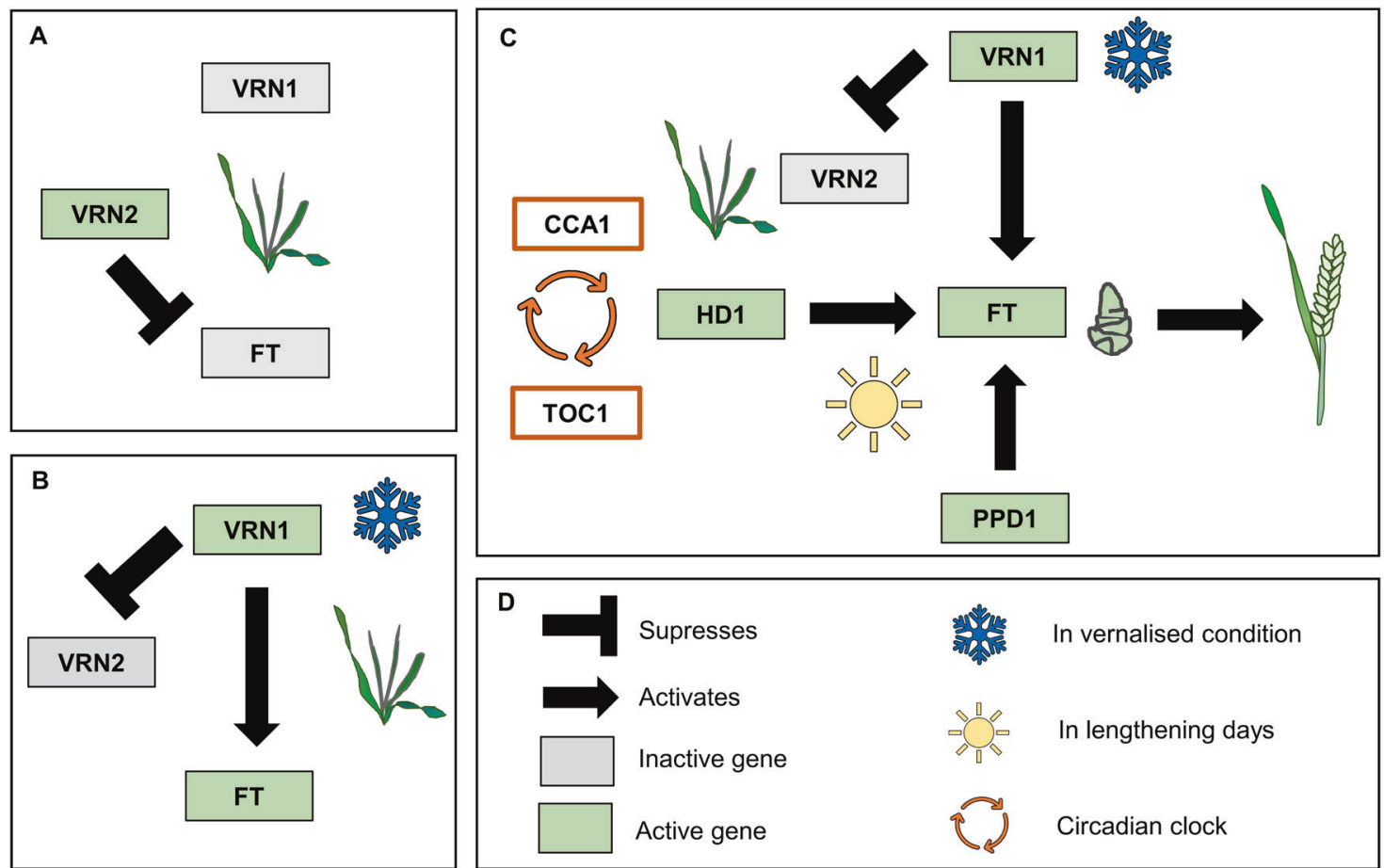

In vernalised condition

In lengthening days

Circadian clock

Fig. 2 Major genes of the flowering pathway. a Gene activity prior to vernalisation (winter wheat). b Gene activity in response to vernalisation. c Gene activity in response to vernalisation and long days, associated with transition to flowering. d Black arrows depict gene action, colour (grey vs. green) illustrates gene expression state (inactive vs. active) and circular arrows represent the feedback loop. 
expression and phenotypic variance (see Banta and Richards (2018) for review). Histone modifications mediate downregulation of the Arabidopsis flowering repressor FLOWERING LOCUS $C$ during vernalisation (Finnegan et al. 2005). In cereals, before vernalisation, histones at the promoter and the first intron of the VRN1 locus have modifications associated with gene repression (histone 3 lysine 27 trimethylation, H3K27me3), and during vernalisation, there is a shift towards modifications typical of active genes (histone 3 lysine 4 trimethylation, H3K4me3) (Oliver et al. 2009). These histone modifications potentially maintain repression of VRN1 before winter and conversely, sustain activity of VRN1 after prolonged cold. This could provide a "memory" of vernalisation, such that chromatin at the VRN1 locus remains in an active state after winter even when temperatures rise, allowing flowering to proceed when days lengthen in spring (Oliver et al. 2009). Presumably, the chromatin state is restored during meiosis, as the vernalisation requirement "resets" in progeny. During seed development, cold conditions while ripening can vernalise the progeny seed, and this memory of vernalisation is retained post seed development, drying and harvest (Gregory and Purvis 1936; Atayde 2019). The implications of this need to be considered during seed increases and cropping situations.

Mutations in the promoter and deletions in the large first intron of VRN1 are both associated with elevated expression of the gene in the absence of cold and accelerated flowering without vernalisation (Kippes et al. 2018). These mutations are found in the VRN1 gene from each of the A, B and D genomes, and give rise to dominant alleles for reduced vernalisation requirement, with the A-genome version conferring the greatest effect (no requirement for cold temperature to flower) relative to the $\mathrm{B}$ - and D-genome alleles (reduced vernalisation requirement, semi-spring types) (Trevaskis et al. 2003). The difference between the sub-genomes is potentially due to the nature of the mutations found in each allele (i.e., promoter insertion plus gene duplication on A genome, intron deletions of differing size on $\mathrm{B}$ and $\mathrm{D}$ genomes).

The first intron of VRNI contains a binding site for the $T$. aestivum glycine-rich RNA-binding protein 2 (TaGRP2), which blocks expression of VRN1 until it is released by cold. During sustained low temperatures, TaGRP2 interacts with a jacalin lectin carbohydratebinding protein TaVER2 (vernalisation-related 2) via OGlcNAc (O-linked $\beta$ - $N$-acetyl glucosamine) (Xiao et al. 2014). This in turn leads to accumulation of VRN1 transcripts and ultimately, flowering. Some wheats have sequence variation (single-nucleotide polymorphisms, SNPs) in the TaGRP2-binding site within the first intron of the A-genome copy of VRN1. These reduce the binding of TaGRP2, and are associated with a moderate reduction of vernalisation requirement (Kippes et al. 2018; Xu et al. 2019). Loss of TaGRP2-binding sites might partially explain why deletions in the first intron are associated with increased VRN1 expression.

VERNALIZATION4 (VRN4), which also reduces vernalisation requirement, is located on chromosome 5DS and arose from translocation of the region from chromosome $5 \mathrm{~A}$ that contains the VRN1 gene (Kippes et al. 2014). VRN4 is associated with increased VRN1 transcript levels from the extra gene copy at the VRN4 locus, and thus reduced vernalisation requirement. The copy of VRN1 at the VRN4 locus contains the intron SNPs described earlier (those which disrupt TaGRP2 binding in VRN1), which potentially explains why $V R N 1$ transcription is elevated in wheats that carry VRN4. The origin of VRN4 in Australian cultivars has been traced to cv. Gabo (Kippes et al. 2015), an important cultivar introducing spring-growth habit and adaptation to the Australian climate.

Other MADS box genes also play roles in regulation of wheat flowering. Two other API/FUL-like genes TaFUL2 and TaFUL3 are paralogues of VRN1 that regulate spike development and also influence flowering time, though to a lesser extent than VRN1 (Li et al. 2019). Another MADS box gene, ODDSOC2 (OS2) (also known as TaAGL33 and TaAGL22 in wheat) is a repressor of flowering downregulated by vernalisation (Greenup et al. 2010, 2011). A Short vegetative phase-like gene, Vegetative to reproductive transition 2 (VRT2), located on the short arm of group 7 chromosomes, was suggested to be a repressor of floral development downregulated by cold (Kane et al. 2005), but subsequent studies found that transcription of this gene increases at low temperatures, and that $V R T 2$ more likely activates flowering in cooperation with VRN1 (Trevaskis et al. 2007; Xie et al. 2019). It remains unclear whether any of these MADS box genes underlie variation in phenology or any other developmental traits.

The gene that triggers long-day-induced flowering of wheat is the functional equivalent of Arabidopsis FLOWERING LOCUS T (FT), referred to here as TaFT1 for FTlike 1 (Turner et al. 2005). FT is proposed to be "florigen", a plant hormone capable of triggering flowering in inductive day-length conditions (Zeevaart 2006). In wheat, TaFT1 is transcribed in long days, but only when VRN1 is active (i.e., in vernalised plants or those containing spring VRN1 alleles, see Fig. 2), consistent with vernalisation being a prerequisite for long-day-induced flowering in winter wheat (Yan et al. 2006). At the shoot apex, the TaFT protein interacts with a bZIP transcription factor (encoded by FLOWERING LOCUS D-LIKE 2, TaFDL2). The resulting TaFT protein complex directly binds to the promoter of VRN1 at sites with an ACGT core motif, and in some genotypes and environments, this promotes further expression of VRN1 (Distelfeld et al. 2009). 
The VRN3 gene, which can reduce the vernalisation requirement of wheat, has been mapped to TaFT1 (Yan et al. 2006). Insertions within the promoter of TaFT1/VRN3 give rise to dominant alleles associated with elevated TaFT1 expression and rapid flowering, irrespective of vernalisation or day length. Conversely, deletion of the B-genome copy of TaFT1 delays flowering, extending the spike development phase and increasing spikelet numbers under long-day conditions (Finnegan et al. 2018). Other genes from the FT family have been identified in cereals. Shaw et al. (2019) found that TaFT2 had a mild effect on time to flowering and a more profound effect on spikelet number, while the FT3 of barley (Hordeum vulgare) was associated with accelerated flowering in short-day conditions (Halliwell et al. 2016).

VRN2 is a repressor of flowering that plays a key role in blocking the long-day flowering response before winter (Fig. 2) (Yan et al. 2004; Trevaskis et al. 2006). The VRN2 locus contains two closely related "zinc-finger CCT" genes (ZCCT1 and ZCCT2), so-called due to the presence of a zinc finger at the $\mathrm{N}$ terminus and a conserved CCT domain first identified in the predicted protein sequences of $C O N$ STANS, CONSTANS-like and TIMING OF CAB EXPRESSION-1 genes (Yan et al. 2004; Kippes et al. 2015; $\mathrm{Li}$ and $\mathrm{Xu} 2017)$. VRN2 is expressed in long days where it represses flowering by suppressing transcription of TaFT1 (Trevaskis et al. 2006; Hemming et al. 2008). This repression likely occurs via protein interactions with NUCLEAR FACTOR - Y (NF-Y) genes (Li et al. 2011). NF-Y proteins interact with proteins containing CCT domains and bind to the CCAAT box of promoters to elicit expression responses (Stephenson et al. 2007). Following winter, in vernalised plants, the VRN1 protein is produced and binds to the promoter of VRN2 and TaFT1. This downregulates VRN2 and so allows the photoperiod pathway to activate TaFT1 in long days, to promote flowering (Trevaskis et al. 2006; Deng et al. 2015). VRN1 binding to the promoter of TaFT1 potentially plays a more direct role in activating the longday flowering response.

The wild-type "winter" phenotype (requirement for vernalisation) requires a functional copy of VRN2. Recessive $V R N 2$ loss-of-function alleles give rise to spring growth habit in diploid wheats and barley, but in a day-lengthdependent matter, where flowering is accelerated in long days. Loss-of-function alleles of VRN2 in hexaploid wheat are unlikely to account for natural variation in phenology due to genome redundancy masking allele effects; however, triple loss-of-function genotypes of hexaploid bread wheat have been generated by inducing and stacking loss-offunction mutants of all three copies of the VRN2 gene (Yan et al. 2004; Distelfeld et al. 2009). This suggests that there may be potential for the generation of new allelic diversity at VRN2 to broaden the adaptation of wheat.

\section{Photoperiod sensitivity}

Sensitivity to day length is largely determined by alleles of the PHOTOPERIOD1 (PPDI) gene, with homoeologous copies on the A, B and D genomes of hexaploid bread wheat (chromosomes 2A, 2B and 2D) (Welsh et al. 1973; Law et al. 1978). PPDl belongs to a pseudoresponse regulator (PRR) family and is also known as PRR37. As for $V R N 2$, the PRR family of proteins feature the CCT motif (Mizuno and Nakamichi 2005). Wild-type alleles of PPD1 have a rhythmic diurnal pattern of gene expression (peak in the middle of the day), and are associated with day-lengthsensitivity, where lengthening/longer days accelerate flowering (Diaz et al. 2012, Shaw et al. 2012). Allelic diversity in PPD1 arises through deletions or a transposon insertion in the promoter, and through copy-number variation (CNV). Diaz et al. (2012) showed that alleles of PPD-B1 (along with $V R N-A 1$ ) were associated with increased copy number of both genes, and resulted in earlier flowering (PPD-Bla) or increased vernalisation requirement $(V R N-A 1 w)$. These results, along with a separate study in durum (Würschum et al. 2017), suggest that copy-number variation is important for the adaptation of wheat. Non-wild-type alleles of PPD1 alter the expression of the gene, leading to elevated transcription throughout the day, and accelerated flowering through elevated TaFT1 expression. This can substitute for long days and reduce day-length sensitivity.

Alleles that confer a strong insensitivity to day length (e.g., an allele of the D-genome copy of PPD1, PPD-DIa, with a deletion in the promoter region) are associated with rapid flowering in all day-length conditions (Diaz et al. 2012; Wilhelm et al. 2009). Other studies (Bentley et al. 2011, 2013) describe the importance of the $P P D-A 1$ and $P P D-B 1$ loci. It is likely that these differences are driven by allele-specific effects (e.g., the nature of discrete mutations in the PPDl gene) rather than simply due to a particular genome. It is worth noting that long days will accelerate flowering to some extent, even in wheats with the alleles of PPD1 that confer strong day-length insensitivity, suggesting that additional genes or pathways can contribute to the long-day flowering response of wheat (Bloomfield et al. 2018). Similarly, flowering of "day-length insensitive" wheats can be further accelerated by elevated ambient temperatures (Hemming et al. 2012).

Alleles of PPD1 that are associated with reduced daylength sensitivity are also associated with an increased rate of spikelet development and decreased spike fertility (Prieto et al. 2018). A recent study attributed a shorter duration of pre-anthesis stem elongation and decreased number of fertile florets to PPD-Dla, highlighting the scope for increased yield potential by selection for photoperiod-sensitive alleles (Perez-Gianmarco et al. 2019). Conversely, it may be beneficial to select for insensitivity in some environments as 
PPD-Dla has been shown to increase the duration of flowering (across all tillers of a plant, not within a single spike) (Jones et al. 2017). This ability of the plant to spread flowering of tillers could be beneficial to minimise the impact of a brief stress event, such as frost or heat, because not all spikes on the plant will be at a stage most sensitive to damage (Lukac et al. 2012).

Genes at other loci are also part of the photoperiodic flowering pathway. Zhang et al. (2016) reported a TaPPDI paralogue, TaPRR73, located on chromosome 4A, was highly expressed in early-flowering wheats and contributed to plant height. A locus on chromosome 7B, TaPPD-B2, was associated with early flowering in long days, and linked to high protein content of grain (Khlestkina et al. 2009).

\section{Circadian clock}

The importance of $P P D 1$, a $P R R$ gene, in determining photoperiod sensitivity of wheat, highlights the fundamental role of the circadian clock in coordination of the day-length response (Mizuno and Nakamichi 2005). The circadian clock is the intrinsic mechanism used by plants to synchronise internal biological processes with the daily fluctuating environment that is cycles of light and temperature between day and night (Ford et al. 2016). Aside from a key role in day-length perception, the circadian clock also regulates other important biological processes, such as photosynthesis, metabolism and the response to biotic and abiotic stress, to maintain synchrony between internal processes and daily changes in the external growing environment.

The plant circadian clock has been studied intensively in Arabidopsis, with much less research undertaken in wheat. The fundamental components appear conserved in cereals, so Arabidopsis remains an exemplar model. The clock consists of negative feedback loops that give rise to rhythmic waves of gene expression through the day-night cycle (see Hsu and Harmer 2014 for review). Circadian clockassociated 1 (CCA1) and late-elongated hypocotyl (LHY) are MYB transcription factor genes with peak transcript levels occurring at dawn. Then there are a series of PRR genes that are expressed sequentially from morning to evening (PRR9, PRR7, PRR5, PRR3 and TIMING OF CAB EXPRESSION 1 (TOC1)). In the morning, CCAl and $L H Y$ repress transcription of TOC1 (also known as PRR1). TOC1 expression peaks in the evening, and this in turn represses $C C A 1$ and $L H Y$, creating a feedback loop. Other components of the circadian clock include ARRHYTHMO/PHYTOCLOCK (LUX/PCL), EARLY FLOWERING 3 (ELF3), EARLY FLOWERING 4 (ELF4) and GIGANTEA (GI) (see Bendix et al. (2015) for review).

The circadian clock of Arabidopsis plays a key role in the photoperiod pathway by regulating diurnal expression of CONSTANS (CO), a light-sensitive activator of FT (Samach et al. 2000, Lazaro et al. 2015). Peak transcript levels of $C O$ occur late in the afternoon (Suarez-Lopez et al. 2001). CO is degraded in darkness, which means that in short days, when dusk arrives early, the peak of CO protein accumulation will occur during the dark, and thus the protein degrades. In long days, peak expression coincides with light when $\mathrm{CO}$ activates $F T$ to induce flowering. TaHDl is a wheat $\mathrm{CO}$ orthologue located on the long arms of chromosome group 6, distal to the TOC1 locus. Like $C O$, TaHDl exhibits diurnal gene expression (peak during the day, low at night) in long days, suggesting conservation of the day-length-sensing mechanisms between Arabidopsis and cereals.

\section{Light perception}

Phytochromes perceive light and so contribute to photoperiod responses and regulation of the circadian clock. There are two interchangeable states of phytochrome chromoprotein, Pr and PFr. The inactive form, Pr, absorbs red light, and the active form, PFr, absorbs light from the far-red regions of the visible spectrum. PFr interacts with phytochrome-interacting factors, helix-loop-helix transcription factors that regulate processes in wheat, like growth responses (towards the direction of sunlight or to minimise shading for example), and flowering (Pearce et al. 2016). The proportion of PFr to the total chromoprotein, known as the phytochrome-photostationary state of the plant, affects architecture (for instance height, tillering capacity and leaf mass per unit area), which is important for light interception, photosynthetic capacity and yield (Evers et al. 2006; Barnes and Bugbee 1991; Casal 1993; Ugarte et al. 2010). Halliday and Davis (2016) suggest that Arabidopsis phytochromes are responsive to temperature and play a role in regulating plant temperature response. In wheat, PHYTOCHROME C (PHYC) is the primary phytochrome that provides light input into the photoperiod flowering pathway (Chen et al. 2014). Unlike PHYC in Arabidopsis, wheat PHYC is stable and does not require other phytochromes for activity (Monte et al. 2003). In long days, PHYC upregulates both PPDI and TaHD1, accelerating flowering via FT1 (Chen et al. 2014; Pearce et al. 2016).

\section{Earliness per se}

Genes that influence duration of the wheat lifecycle in conditions where vernalisation and photoperiod requirements have been met, are described as "Earliness per se" (EPS) loci (Snape et al. 2001). An emerging theme is that many cereal EPS genes correspond to components of the 
circadian clock. The EPS- $3 A^{m}$ gene of Triticum monococcum is an orthologue of the Arabidopsis LUX/PCL gene (Gawronski and Schnurbusch 2012). Another EPS locus, $E p s-A^{m} 1$, encompasses a deletion of the wheat $E L F 3$ gene (Zikhali et al. 2016). Ochagavía et al. (2019) reports that allelic differences at TaELF3 confer differing levels of sensitivity to temperature; earliness was associated with an increased sensitivity to temperature during the late reproductive phase of development in hexaploid wheat. The same study also revealed temperature-dependent suppression of TaGI due to TaELF3. Both genes have also been associated with phytochrome-mediated light signalling and the circadian clock (Ford et al. 2016).

\section{Secondary adaptive traits}

Adapted wheat contains allelic combinations of the multiple genes affecting phenology to ensure that the lifecycle is appropriate to the growing conditions. Secondary to this, other traits are also important and must be matched to phenology and the environment.

\section{Winter hardiness}

In cold climates where wheat is sown in autumn, cultivars require a degree of "winter hardiness" to survive freezing temperatures during the vegetative phase. Key to this is the ability to acclimate to cold, whereby freezing tolerance is acquired in response to low temperatures. This can occur in conjunction with the vernalisation response.

Cold acclimation is mediated by C-repeat-binding factors (CBF), also known as dehydration-responsive element binding (DREB) proteins. CBF/DREBs contain a DNA motif of approximately 60 amino acids that bind specific promoter elements (CRT-DRE boxes) of target genes leading to their activation, for instance, late embryogenesis abundant (LEA) (also known as dehydrins (DHNS)) and cold-regulated (COR) genes. Li and Chen (1997) found higher accumulation of DHNS transcripts in winter cereals subject to cold relative to spring types, given the same cold acclimation treatment. Upregulation of a cereal-specific COR gene (wlt10) has been reported in response to low temperature, with accumulation of transcripts more rapid and sustained in a cold-tolerant winter background (Ohno et al. 2001). Soon after exposure to cold, inducer of $c b f$ expression 1 (ICE1) is upregulated, followed by expression of $C O R$ genes some hours later. In Arabidopsis, freezing tolerance is related to the subsequent production of cryoprotectants, such as sucrose, raffinose and hydrophilic peptides, which protect membranes against dehydration during freezing (Thomashow 2010). In wheat, changes in the leaf content of lipids, sugars, sugar alcohols and amino acids have been associated with cold acclimation and metabolomics suggested as a measurement tool for chilling and frost tolerance (Cheong et al. 2019).

Not only have $C B F s$ been identified as key components of the cold acclimation pathway, they have also been found to contribute to allelic variation. At least $15 C B F s$ have been identified in wheat with an important locus, $F R 2$ comprising a cluster of $C B F$ genes close to VRN1 on group 5 chromosomes. Copy-number variation of $C B F$ genes at FRA2 was attributed to increased winter hardiness and therefore adaptation in European winter wheat (Würschum et al. 2016), while variation at the $F R B 2$ locus was associated with frost tolerance, flowering time and improved yield (Pearce et al. 2013; Badawi et al. 2007; Eagles et al. 2016). The wild-type allele of FRB2 is often present in winter wheat, and is considered advantageous for adaptation and yield in frost-prone environments, opposed to a large deleted segment frequently found in spring types, which should be beneficial in areas with low-frost risk (Eagles et al. 2016, 2018). Genetic linkage of the VRN1 and FR2 loci, and the association of vernalisation sensitivity with particular alleles of $F R B 2$, suggests that co-selection of these independent loci is important for adaptation.

There are broader functions for $C B F$ genes, including regulation of growth and development. These transcription factors are members of the APETALA 2/ethylene-responsive element binding gene family also involved in floral organ identity and drought and salinity stress response (Yamaguchi-Shinozaki and Shinozaki 2006). A controlled condition experiment involving transgenic barley overexpressing TaDREB2 and TaDREB3, showed that plants that constitutively expressed the transgenes grew more slowly, flowered 2-3 weeks later and had changed activity of other $C B F s$ and improved frost tolerance (Morran et al. 2011).

The cold acclimation pathway also potentially plays a role in regulating plant architecture. A feature of many winter-type wheats with a high degree of winter hardiness is early prostrate growth habit, where plants have large tiller angles at the vegetative stage of development ( $\mathrm{Li}$ and Chen 1997). Prostrate plant types in the vegetative stage might confer adaptation to cold and frosty winters by allowing the plant to be covered by a blanket of snow that protects the crop against freezing temperatures.

\section{Tillering}

Aside from prostrate growth habit, another feature of winter wheat is a high degree of tillering, due to the increased duration of the vegetative phase (a vernalisation-requiring wheat will take longer to switch to reproductive development relative to a vernalisation-insensitive plant). A larger number of tillers can increase yield in a high-input (water, nutrient) 
system due to production of additional fertile spikes. In water-limiting environments however, a higher tiller number may not contribute to increased yield, with additional tillers unable to support fertile spikes. A tiller-reducing gene in wheat, TIN, has been identified and studied for yield effects in water-limiting environments of Australia (Richards 1988). To date, there are conflicting reports of the benefit or disadvantage of reduced tillering due to TIN in Australian farming systems, and it is likely that the limited number of backgrounds in which the gene has been studied, along with a strong genotype $\times$ environment interaction is confounding (Mitchell et al. 2012; Hendriks et al. 2016; Fletcher et al. 2019). Exploring the optimal tillering potential in different phenological types would be interesting.

\section{Plant height}

Final plant height is another developmental trait that influences adaptation. In high-input irrigated farming systems, cultivars with short stature are required to prevent lodging (SanchezGarcia and Bentley 2019), whereas taller cultivars are often suited to low-input dryland systems such as the Australian wheat belt (Mathews et al. 2006). A major determinant of the final plant height is the endogenous supply and sensitivity to the hormone gibberellic acid (GA), which is involved in most aspects of development, including germination, vegetative growth, stem elongation and production of flowers and seeds (see Yamaguchi 2008). GA is also implicated in stress response pathways, for example, drought and salinity (Llanes et al. 2016). Other research shows that GA is an important component of the flowering pathway of grasses (MacMillan et al. 2005) and in barley, early flowering triggered by mutations in $H v E L F 3$ requires elevated GA biosynthesis (Boden et al. 2014).

GA promotes growth by an interaction with, and removal of the effect of growth-inhibitory DELLA proteins. In this process, bioactive GA binds to a receptor protein GAinsensitive dwarf 1 (GID1) and DELLA to form a complex that is targeted by an E3 ubiquitin ligase, degrading DELLA (see Sun (2010) for review).

REDUCED HEIGHT 1 (Rht-B1, RHT1, chromosome 4BS) and REDUCED HEIGHT 2 (Rht-D1, RHT2, chromosome 4DS) are homoeologous copies of the same DELLA-encoding gene on the $\mathrm{B}$ and $\mathrm{D}$ genomes. Mutations in these genes give rise to alleles conferring semidwarf habit (reduced stem elongation). These mutations create premature stop codons with subsequent truncated proteins unable to form the GA-GID-DELLA complex. Instead of being degraded, DELLA then accumulates and represses growth. Dwarf alleles $R h t-B 1 b$ and $R h t-D 1 b$ have been deployed in plant breeding to develop wheat adapted to environments with high-yield potential.
Otherwise known as green revolution genes, they facilitate use of irrigation and nitrogen fertiliser to boost biomass production, harvest index and yield, by ensuring that crops are adapted to high-input farming systems and do not lodge (Peng et al. 1999). Dwarf alleles can be traced to a Japanese landrace, which was introgressed with US germplasm to create the cultivar Norin-10. This germplasm was then deployed by Norman Borlaug in the International Maize and Wheat Improvement Centre (CIMMYT) breeding program. Alleles from Norin-10 then spread to breeding programs throughout the world via cultivars Pitic 62, Penjamo 62 and their progeny. The success of these cultivars is due to their reduced height and also likely improvement in productive tiller number to increase yield (Evans 1975). Other dwarf alleles of Rht-BI and $R h t-D l$ have been identified at these loci conferring differing levels of height reduction that may be useful for adaptation in different environments (Pearce et al. 2011).

An international trial found that in high-yielding environments, on average, there is no yield penalty associated with $R h t-B l b$ and $R h t-D l b$ relative to wild-type alleles in nearisogenic tall lines (Mathews et al. 2006). In low-yielding sites however, semi-dwarfs yielded less than the tall wild-type NIL, and so breeding for taller semi-dwarfs, or "short-talls" would be ideal for adaptation and yield in these environments. This result may reflect the disadvantage of dwarf alleles of Rht-BI and Rht-Dl loci, that the whole plant is insensitive to GA. This means that after germination, the growing sheath that delivers the shoot from the seed to soil surface (coleoptile) is also reduced in length. For this reason, $R h t-B l b$ - and $R h t-D l b$ carrying lines cannot be sown as deep as their wild-type counterparts. This can have a negative impact on establishment and the ability to capture soil moisture deep in the profile (Whan 1976).

Other dwarfing genes responsive to GA and so with potential to maintain long coleoptiles have been described in wheat (Ellis et al. 2004). Recently, a mutant with lower endogenous GA content (originally described in durum) was identified as Rht18 on chromosome 6AS (Ford et al. 2018). An agronomic study (Tang 2016) suggests that $R h t 18$ is a promising candidate to replace $R h t-D 1 b$. Haque et al. (2011) proposed that Rht14 and Rht16 are alleles at the same locus, and based on the map location of Rht 24 in Chinese Spring (Würschum et al. 2017), it is possible that this gene is allelic to Rht18. A distinct locus on chromosome 6A, Rht25, reduced height to a lesser extent than Rht$B 1 b$ and Rht-DIb (Mo et al. 2018), and may be a good candidate to produce "short-talls". Other dwarfing genes, including $R h t 4, R h t 5$ and $R h t 8$, are attractive breeding targets for adaptation if they are not associated with growth penalties such as short coleoptiles (Ellis et al. 2004).

There is a coincidence of height and phenology, and studies have detected an association of VRNI and PPDI with 


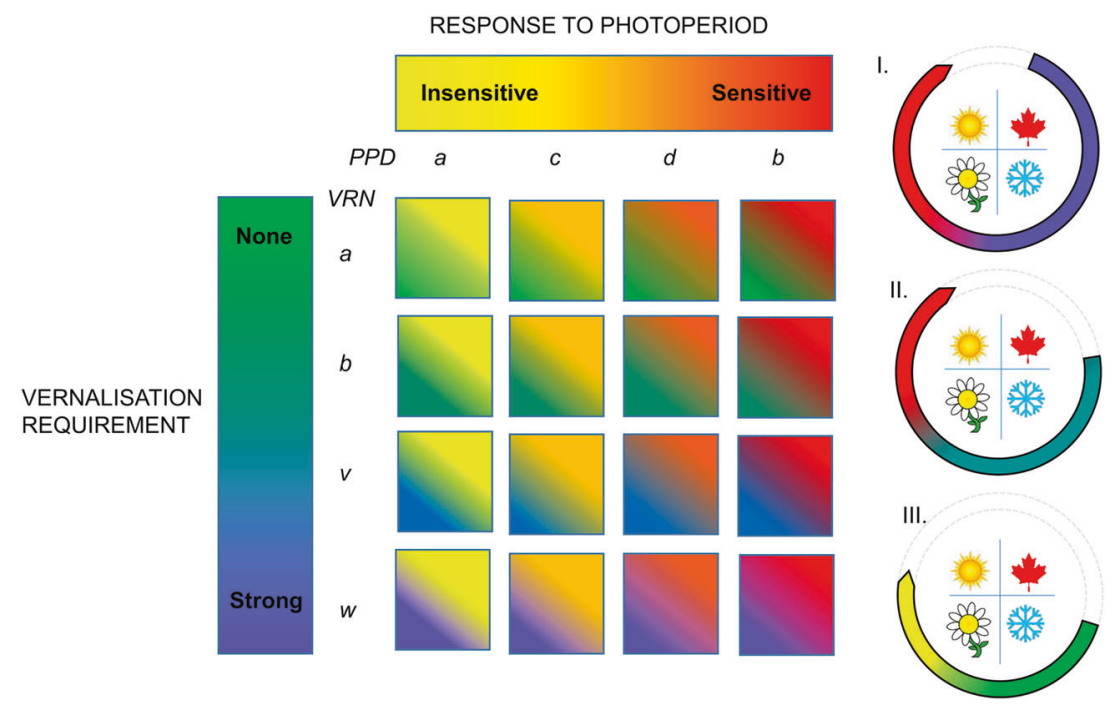

Fig. 3 Seasonal lifecycle of wheat: major genes in the farming system. Photoperiod response from insensitive (yellow) to sensitive (red) conferred by alleles $(a, c, d, b)$ at PPD1-D loci and vernalisation requirement from none (green) to strong (lilac) conferred by alleles ( $a$, $b, v, w)$ at VRN1-A loci (allele nomenclature from Cane et al. 2013)

plant height in both diverse and structured genetic wheat populations (Camargo et al. 2018; Wilhelm et al. 2013). It is important to consider dwarfing genes and phenological variation together as gene-gene and gene-environment interactions will affect the final plant height.

\section{Quantitative traits in the farming system}

Phenology is fundamental to the adaptation of wheat. This is particularly evident in the cropping regions of Australia. Cultivars with a strong vernalisation requirement and sensitivity to day length are suited to regions of Australia which have cold winters and a high risk of frost (Fig. 3). Most of the wheatgrowing regions of Australia have milder winters and hot and dry summers, so wheats with a shorter lifecycle from lack of vernalisation requirement and day-length sensitivity (spring types) are traditionally sown after late autumn rain and flower early in spring, before temperature and drought stress in summer (Fig. 3). In response to a changing climate, a field and simulation study assessed performance of different combinations of development alleles in near-isogenic lines (Hunt et al. 2019), and suggested that a shift to earlier sowing of slowerdeveloping genotypes in these regions would increase yield, despite the predicted decrease in rainfall and increase in temperature. For this to occur, Australian breeders need to develop cultivars with slower rates of development and flowering behaviour matched to each growing environment. This is possible with the use of high-throughput marker platforms in breeding programmes to select allelic combinations for adaptation (Grogan et al. 2016). Other traits, such as plant changes life-cycle duration and adaptation to different growing environments and times of sowing: I. Adaptation to cold winters and early sowing - slow-developing wheat, II. Adaptation to mild wintermid-developing wheat, III. Adaption to hot summer and late sowingfast-developing wheat.

architecture and tolerance to climatic stress, are also important to optimise yield in each farming system. The complex network of genes that underlie adaptation interact strongly with the environment, and in a changing climate, breeding new cultivars and changing agronomic practices will be required to ensure future crop success.

\section{Future possibilities}

The current understanding of phenology and adaptation was developed through reductionist approaches, such as gene mapping in biparental populations, and detailed studies of NILs, to determine the genetic basis and develop molecular markers for individual traits. These approaches are often time consuming and labour intensive. Emerging technologies, including whole-genome sequencing, highthroughput genotyping and genome-wide analytical techniques, are accelerating progress and allow research to be conducted at a larger, more holistic scale. The transcriptome for instance, captures the response of the genome to the environment. Transcriptome analysis of diverse genetic material adapted to different climates around the globe should provide new insights. Other data, such as proteomics and metabolomics, will also be invaluable, and analytical techniques such as machine learning, utilised to handle different types of data at scale. Technologies that allow rapid resolution of complex systems will be important to harness quantitative traits for future crop improvement, particularly where these traits exhibit strong environmental interactions. 


\section{Conclusion}

Quantitative traits are complex due to the action of multiple genes and their interactions with each other and the environment, giving rise to a continuous distribution of phenotypes. Phenology and plant architecture are examples of quantitative traits that are fundamental contributors to the adaptation of wheat. Major loci include $V R N, P P D, E P S, R H T$ and genes from the $C B F /$ $D R E B$ family, though there are many other minor-affect loci that are important for adaptation. It is a worthy pursuit to characterise the genes that underlie these traits, and most relevant if the effect of alleles can be assessed in the growing environment that best reflects the farmer's field. In this way, breeders can target allelic combinations for specific wheat-growing regions and farm management systems. As the global climate changes, new allelic combinations may be required for the adaptation of wheat. For breeders to deliver future adapted cultivars, expedited methods of research to understand gene pathways in relevant environments alongside development of markers for selection are required.

Acknowledgements This review was undertaken during Jessica Hyles' $\mathrm{PhD}$. We are grateful to Dr Howard Eagles for his mentorship and the University of Sydney for financial support. The authors thank the reviewers for their thoughtful critique.

\section{Compliance with ethical standards}

Conflict of interest The authors declare that they have no conflict of interest.

Publisher's note Springer Nature remains neutral with regard to jurisdictional claims in published maps and institutional affiliations.

Open Access This article is licensed under a Creative Commons Attribution 4.0 International License, which permits use, sharing, adaptation, distribution and reproduction in any medium or format, as long as you give appropriate credit to the original author(s) and the source, provide a link to the Creative Commons license, and indicate if changes were made. The images or other third party material in this article are included in the article's Creative Commons license, unless indicated otherwise in a credit line to the material. If material is not included in the article's Creative Commons license and your intended use is not permitted by statutory regulation or exceeds the permitted use, you will need to obtain permission directly from the copyright holder. To view a copy of this license, visit http://creativecommons. org/licenses/by/4.0/.

\section{References}

Amir J, Sinclair TR (1991) A model of the temperature and solarradiation effects on spring wheat growth and yield. Field Crops Res 28:47-58

Angus JF, Moncur MW (1977) Water stress and phenology in wheat. Aust J Agric Res 28:177-181
Atayde RJ (2019) The effect of low temperature during seed development on flowering in wheat (Triticum aestivum L.) Honours dissertation, Charles Sturt University

Badawi M, Danyluk J, Boucho B, Houde M, Sarhan F (2007) The CBF gene family in hexaploid wheat and its relationship to the phylogenetic complexity of cereal CBFs. Mol Genet Genomics 277:533-554

Banta JA, Richards CL (2018) Quantitative epigenetics and evolution. Heredity 121:210-224

Barnes C, Bugbee B (1991) Morphological responses of wheat to changes in phytochrome photoequilibrium. Plant Physiol 97:359-365

Bendix C, Marshall CM, Harmon FG (2015) Circadian clock genes universally control key agricultural traits. Mol Plant 8:1135-1152

Bentley AR, Horsnell R, Werner CP, Turner AS, Rose GA, Bedard C et al. (2013) Short, natural, and extended photoperiod response in BC2F4 lines of bread wheat with different photoperiod-1 (Ppd-1) alleles. J Exp Bot 64:1783-1793

Bentley AR, Turner AS, Gosman N, Leigh FJ, Maccaferri M, Dreisigacker S et al. (2011) Frequency of photoperiod-insensitive Ppd-A1a alleles in tetraploid, hexaploid and synthetic hexaploid wheat germplasm. Plant Breed 130:10-15

Bloomfield MT, Hunt JR, Trevaskis B, Ramm K, Hyles J (2018) Ability of alleles of PPD1 and VRN1 genes to predict flowering time in diverse Australian wheat (Triticum aestivum) cultivars in controlled environments. Crop Pasture Sci 69:1061-1075

Boden SA, Weiss D, Ross JJ, Davies NW, Trevaskis B, Chandler PM et al. (2014) Early flowering3 regulates flowering in spring barley by mediating gibberellin production and flowering locus $\mathrm{T}$ expression. Plant Cell 26:1557-1569

Camargo AV, Mackay I, Mott R, Han JW, Doonan JH, Askew K et al. (2018) Functional mapping of quantitative trait loci (QTLs) associated with plant performance in a wheat MAGIC mapping population. Front Plant Sci 9:887

Cane K, Eagles HA, Laurie DA, Trevaskis B, Vallance N, Eastwood RF et al. (2013) Ppd-B1 and Ppd-D1 and their effects in southern Australian wheat. Crop Pasture Sci 64:100-114

Casal JJ (1993) Novel effects of phytochrome status on reproductive shoot growth in Triticum-Aestivum L. N. Phytol 123:45-51

Chen A, Li C, Hu W, Lau MY, Lin H, Rockwell NC et al. (2014) Phytochrome $\mathrm{C}$ plays a major role in the acceleration of wheat flowering under long-day photoperiod. Proc Natl Acad Sci USA 111:10037-10044

Cheong BE, HO WWH, Biddulph B, Wallace X, Rathjen T, Rupasinghe TWT et al. (2019) Phenotyping reproductive stage chilling and frost tolerance in wheat using targeted metabolome and lipidome profiling. Metabolomics 15:144

Chouard P (1960) Vernalization and its relations to dormancy. Annu Rev Plant Physiol Plant Mol Biol 11:191-238

Danyluk J, Kane NA, Breton G, Limin AE, Fowler DB, Sarhan F (2003) TaVRT-1, a putative transcription factor associated with vegetative to reproductive transition in cereals. Plant Physiol 132:1849-1860

Deng WW, Casao MC, Wang PH, Sato K, Hayes PM, Finnegan EJ et al. (2015) Direct links between the vernalization response and other key traits of cereal crops. Nat Commun 6:5882

Diaz A, Zikhali M, Turner AS, Isaac P, Laurie DA (2012) Copy number variation affecting the photoperiod-B1 and vernalizationA1 genes is associated with altered flowering time in wheat (Triticum aestivum). PLoS ONE 7:e33234

Distelfeld A, Li C, Dubcovsky J (2009) Regulation of flowering in temperate cereals. Curr Opin Plant Biol 12:178-184

Distelfeld A, Tranquilli G, Li CX, Yan LL, Dubcovsky J (2009) Genetic and molecular characterization of the VRN2 loci in tetraploid wheat. Plant Physiol 149:245-257

Dreccer MF, Fainges J, Whish J, Ogbonnaya FC, Sadras VO (2018) Comparison of sensitive stages of wheat, barley, canola, chickpea 
and field pea to temperature and water stress across Australia. Agric Meteorol 248:275-294

Eagles HA, Hyles J, Wilson J, Cane K, Forrest KL, Hayden MJ et al. (2018) A linked SNP marker to genotype Fr-B2 in wheat. Crop Pasture Sci 69:859-863

Eagles HA, Wilson J, Cane K, Vallance N, Eastwood RF, Kuchel H et al. (2016) Frost-tolerance genes Fr-A2 and Fr-B2 in Australian wheat and their effects on days to heading and grain yield in lower rainfall environments in southern Australia. Crop Pasture Sci 67:119-127

Ellis MH, Rebetzke GJ, Chandler P, Bonnett D, Spielmeyer W, Richards RA (2004) The effect of different height reducing genes on the early growth of wheat. Funct Plant Biol 31:583-589

Evans LT, Wardlaw IF, Fischer RA (1975) Wheat. In: Evans LT (ed) Crop Physiology: Some case histories. Cambridge University Press, London

Evers JB, Vos J, Andrieu B, Struik PC (2006) Cessation of tillering in spring wheat in relation to light interception and red: Far-red ratio. Ann Bot 97:649-658

Feekes W (1941) De tarwe en haar milieu [Wheat and its environment]. Verslagen van de Technische Tarwe Comm 17:523-888

Finnegan J, Kovac KA, Jaliqot E, Sheldon CC, Peacock JW, Dennis ES (2005) The downregulation of flowering locus C (FLC) expression in plants with low levels of DNA methylation and by vernalization occurs by distinct mechanisms. Plant J 44:420-432

Finnegan EJ, Ford B, Wallace X, Pettolino F, Griffin PT, Schmitz RJ et al. (2018) Zebularine treatment is associated with deletion of FT-B1 leading to an increase in spikelet number in bread wheat. Plant Cell Environ 41:1346-1360

Fletcher A, Rebetzke G, Ogden G (2019) Comparing the yield of reduced tillering wheat genotypes at different sowing densities. 19th Australian Agronomy Conference. Wagga Wagga, NSW, Australia

Flohr BM, Hunt JR, Kirkegaard JA, Evans JR (2017) Water and temperature stress define the optimal flowering period for wheat in south-eastern Australia. Field Crops Res 209:108-119

Ford BA, Foo E, Sharwood R, Karafiatova M, Vrana J, MacMillan C et al. (2018) Rht18 semidwarfism in wheat is due to increased GA 2-oxidaseA9 expression and reduced GA content. Plant Physiol 177:168-180

Ford B, Deng W, Clausen J, Oliver S, Boden S, Hemming M et al. (2016) Barley (Hordeum vulgare) circadian clock genes can respond rapidly to temperature in an early flowering 3 -dependent manner. J Exp Bot 67:5517-5528

Gawronski P, Schnurbusch T (2012) High-density mapping of the earliness per se-3A (Eps-3A) locus in diploid einkorn wheat and its relation to the syntenic regions in rice and Brachypodium distachyon L. Mol Breed 30:1097-1108

Greenup AG, Sasani S, Oliver SN, Talbot MJ, Dennis ES, Hemming MN et al. (2010) ODDSOC2 is a MADS box floral repressor that is down-regulated by vernalization in temperate cereals. Plant Physiol 153:1062-1073

Greenup AG, Sasani S, Oliver SN, Walford SA, Millar AA, Trevaskis B (2011) Transcriptome analysis of the vernalization response in Barley (Hordeum vulgare) Seedlings. PLoS One 6:e17900

Gregory FG, Purvis ON (1936) Vernalization of winter rye during ripening. Nature 138:973-973

Grogan SM, Brown-Guedira G, Haley SD, McMaster GS, Reid SD, Smith J et al. (2016) Allelic variation in developmental genes and effects on winter wheat heading date in the US Great Plains. PLoS One 11:e0152852

Haque MA, Martinek P, Watanabe N, Kuboyama T (2011) Genetic mapping of gibberellic acid-sensitive genes for semi-dwarfism in durum wheat. Cereal Res Commun 39:171-178

Halliday KJ, Davis SJ (2016) Light-sensing phytochromes feel the heat. Science 354:832-833
Halliwell J, Borrill P, Gordon A, Kowalczyk R, Pagano ML, Saccomanno B et al. (2016) Systematic investigation of FLOWERING LOCUS T-like Poaceae gene families identifies the short-day expressed flowering pathway gene, TaFT3 in Wheat (Triticum aestivum L.). Front Plant Sci 7:857

Haun JR (1973) Visual quantification of wheat development. Agron J 65:116-119

Hemming MN, Peacock WJ, Dennis ES, Trevaskis B (2008) Lowtemperature and daylength cues are integrated to regulate flowering locus $\mathrm{T}$ in barley. Plant Physiol 147:355-366

Hemming MN, Walford SA, Fieg S, Dennis ES, Trevaskis B (2012) Identification of high-temperature-responsive genes in cereals. Plant Physiol 158:1439-1450

Hendriks W, Kirkegaard JA, Lilley JM, Gregory PJ, Rebetzke GJ (2016) A tillering inhibition gene influences root-shoot carbon partitioning and pattern of water use to improve wheat productivity in rainfed environments. J Exp Bot 67:327-340

Hsu PY, Harmer SL (2014) Wheels within wheels: the plant circadian system. Trends Plant Sci 19:240-249

Hunt JR, Lilley JM, Trevaskis B, Flohr BM, Peake A, Fletcher A et al. (2019) Early sowing systems can boost Australian wheat yields despite recent climate change. Nat Clim Chang 9:244-247

Hyles J, Vautrin S, Pettolino F, MacMillan C, Stachurski Z, Breen J et al. (2017) Repeat-length variation in a wheat cellulose synthase-like gene is associated with altered tiller number and stem cell wall composition. J Exp Bot 68:1519-1529

Jones HE, Lukac M, Brak B, Martinez-Eixarch M, Alhomedhi A, Gooding MJ et al. (2017) Photoperiod sensitivity affects flowering duration in wheat. J Agric Sci 155:32-43

Kane NA, Danyluk J, Tardif G, Ouellet F, Laliberte JF, Limin AE et al. (2005) TaVRT-2, a member of the StMADS-11 clade of flowering repressors, is regulated by vernalization and photoperiod in wheat. Plant Physiol 138:2354-2363

Kato K, Mori Y, Beiles A, Nevo E (1997) Geographical variation in heading traits in wild emmer wheat, Triticum dicoccoides. I. Variation in vernalization response and ecological differentiation. Theor Appl Genet 95:546-552

Khlestkina EK, Giura A, Roder MS, Borner A (2009) A new gene controlling the flowering response to photoperiod in wheat. Euphytica 165:579-585

Kippes N, Guedira M, Lin L, Alvarez MA, Brown-Guedira GL, Dubcovsky J (2018) Single nucleotide polymorphisms in a regulatory site of VRN-A1 first intron are associated with differences in vernalization requirement in winter wheat. Mol Genet Genomics 293:1231-1243

Kippes N, Zhu J, Chen A, Vanzetti L, Lukaszewski A, Nishida H et al. (2014) Fine mapping and epistatic interactions of the vernalization gene VRN-D4 in hexaploid wheat. Mol Genet Genomics 289:47-62

Kippes N, Debernardi JM, Vasquez-Gross HA, Akpinar BA, Budak H, Kato $\mathrm{K}$ et al. (2015) Identification of the VERNALIZATION 4 gene reveals the origin of spring growth habit in ancient wheats from South Asia. Proc Natl Acad Sci USA 112:5401-5410

Kirby EJM (1988) Analysis of leaf, stem and ear growth in wheat from terminal spikelet stage to anthesis. Field Crops Res 18:127-140

Large EC (1954) Growth stages in cereals-illustration of the Feekes scale. Plant Pathol 3:128-129

Law CN, Sutka J, Worland AJ (1978) Genetic study of day-length response in wheat. Heredity 41:185-191

Lazaro A, Mouriz A, Pineiro M, Jarillo JA (2015) Red light-mediated degradation of CONSTANS by the E3 ubiquitin ligase HOS1 regulates photoperiodic flowering in Arabidopsis. Plant Cell 27:2437-2454

Li CX, Distelfeld A, Comis A, Dubcovsky J (2011) Wheat flowering repressor VRN2 and promoter $\mathrm{CO} 2$ compete for interactions with NUCLEAR FACTOR-Y complexes. Plant J 67:763-773 
Li CX, Lin HQ, Chen A, Lau M, Jernstedt J, Dubcovsky J (2019) Wheat VRN1, FUL2 and FUL3 play critical and redundant roles in spikelet. Dev spike determinacy Dev 146:dev175398

Li PH, Chen THH (1997) Plant cold hardiness: molecular biology, biochemistry and physiology. Plenum Press, New York

Li YP, Xu ML (2017) CCT family genes in cereal crops: a current overview. Crop J 5:449-458

Llanes A, Andrade A, Masciarelli O, Alemano S, Luna V (2016) Drought and salinity alter endogenous hormonal profiles at the seed germination phase. Seed Sci Res 26:1-13

Lukac M, Gooding MJ, Griffiths S, Jones HE (2012) Asynchronous flowering and within-plant flowering diversity in wheat and the implications for crop resilience to heat. Ann Bot 109:843-850

MacMillan CP, Blundell CA, King RW (2005) Flowering of the grass Lolium perenne. Effects of vernalization and long days on gibberellin biosynthesis and signaling. Plant Physiol 138:1794-1806

Mandel MA, Yanofsky MF (1995) A gene triggering flower formation in Arabidopsis. Nature 377:522-524

Mathews KL, Chapman SC, Trethowan R, Singh RP, Crossa J, Pfeiffer W et al. (2006) Global adaptation of spring bread and durum wheat lines near-isogenic for major reduced height genes. Crop Sci 46:603-613

McMaster GS, Wilhelm WW (1997) Growing degree-days: one equation, two interpretations. Agric Meteorol 87:291-300

Mitchell JH, Chapman SC, Rebetzke GJ, Bonnett DG, Fukai S (2012) Evaluation of a reduced-tillering (tin) gene in wheat lines grown across different production environments. Crop Pasture Sci 63:128-141

Mizuno T, Nakamichi N (2005) Pseudo-response regulators (PRRs) or true oscillator components (TOCs). Plant Cell Physiol 46:677-685

Mo Y, Vanzetti LS, Hale I, Sagnolo EJ, Guidobaldi F, Al-Oboudi J et al. (2018) Identification and characterization of Rht25, a locus on chromosome arm 6AS affecting wheat plant height, heading time, and spike development. Theor Appl Genet 131:2021-2035

Moncur MW (1981) Floral initiation in field crops: an atlas of scanning electron micrographs Division of Land Use Research, Commonwealth Scientific and Industrial Research Organisation, Canberra

Monte E, Alonso JM, Ecker JR, Zhang Y, Li X, Young J et al. (2003) Isolation and characterization of phyC mutants in Arabidopsis reveals complex crosstalk between phytochrome signaling pathways. Plant Cell 15:1962-1980

Morran S, Eini O, Pyvovarenko T, Parent B, Singh R, Ismagul A et al. (2011) Improvement of stress tolerance of wheat and barley by modulation of expression of DREB/CBF factors. Plant Biotechnol J 9:230-249

Ochagavía H, Prieto P, Zikhali M, Griffiths S, Slafer GA (2019) Earliness Per Se by Temperature Interaction on Wheat Development. Sci Rep 9:2584

Ohno R, Takumi S, Nakamura C (2001) Expression of a coldresponsive Lt-Cor gene and development of freezing tolerance during cold acclimation in wheat (Triticum aestivum L.). J Exp Bot 52:2367-2374

Oliver SN, Finnegan EJ, Dennis ES, Peacock WJ, Trevaskis B (2009) Vernalization-induced flowering in cereals is associated with changes in histone methylation at the VERNALIZATION1 gene. Proc Natl Acad Sci USA 106:8386-8391

Pearce S, Kippes N, Chen A, Debernardi JM, Dubcovsky J (2016) RNA-seq studies using wheat PHYTOCHROME B and PHYTOCHROME C mutants reveal shared and specific functions in the regulation of flowering and shade-avoidance pathways. BMC Plant Biol 16:141

Pearce S, Saville R, Vaughan SP, Chandler PM, Wilhelm EP, Sparks CA et al. (2011) Molecular characterization of Rht-1 dwarfing genes in hexaploid wheat. Plant Physiol 157:1820-1831
Pearce S, Zhu J, Boldizsar A, Vagujfalvi A, Burke A, GarlandCampbell $\mathrm{K}$ et al. (2013) Large deletions in the CBF gene cluster at the Fr-B2 locus are associated with reduced frost tolerance in wheat. Theor Appl Genet 126:2683-2697

Peng J, Richards DE, Hartley NM, Murphy GP, Devos KM, Flintham JE et al. (1999) 'Green revolution' genes encode mutant gibberellin response modulators. Nature 400:256-261

Percival J (1921) The wheat plant; A monograph. Duckworth and Co., London

Perez-Gianmarco TI, Slafer GA, Gonzalez FG (2019) Photoperiodsensitivity genes shape floret development in wheat. J Exp Bot 70:1339-1348

Porter JR, Gawith M (1999) Temperatures and the growth and development of wheat: a review. Eur J Agron 10:23-36

Prieto P, Ochagavia H, Savin R, Griffiths S, Slafer GA (2018) Dynamics of floret initiation/death determining spike fertility in wheat as affected by Ppd genes under field conditions. J Exp Bot 69:2633-2645

Rawson HM (1970) Spikelet number, its control and relation to yield per ear in wheat. Aust J Biol Sci 23:1-15

Richards RA (1988) A tiller inhibitor gene in wheat and its effect on plant-growth. Aust J Agric Res 39:749-757

Robertson MJ, Brooking IR, Ritchie JT (1996) Temperature response of vernalization in wheat: Modelling the effect on the final number of mainstem leaves. Ann Bot 78:371-381

Samach A, Onouchi H, Gold SE, Ditta GS, Schwarz-Sommer Z, Yanofsky MF et al. (2000) Distinct roles of CONSTANS target genes in reproductive development of Arabidopsis. Science 288:1613-1616

Sanchez-Garcia M, Bentley AR (2019) Chapter 9 Global Journeys of Adaptive Wheat Genes. In: Thomas Miedaner and Viktor Korzun (eds), Applications of Genetic and Genomic Research in Cereals Elsevier Woodhead Publishing, Amsterdam

Shaw LM, Lyu B, Turner R, Li CX, Chen FJ, Han XL et al. (2019) FLOWERING LOCUS T2 regulates spike development and fertility in temperate cereals. J Exp Bot 70:193-204

Shaw LM, Turner AS, Laurie DA (2012) The impact of photoperiod insensitive Ppd-1a mutations on the photoperiod pathway across the three genomes of hexaploid wheat (Triticum aestivum). Plant J 71:71-84

Slafer GA, Kantolic AG, Appendino ML, Tranquilli G, Miralles DJ, Savin R (2015) Genetic and environmental effects on crop development determining adaptation and yield. In: Sadras V, Calderini D (eds) Crop Physiology: applications for genetic improvement and agronomy, 2nd edn, Elsevier Academic Press, USA. pp 285-319

Slafer GA, Rawson HM (1994) Sensitivity of wheat phasic development to major environmental-factors - a reexamination of some assumptions made by physiologists and modelers. Aust J Plant Physiol 21:393-426

Snape JW, Butterworth K, Whitechurch E, Worland AJ (2001) Waiting for fine times: genetics of flowering time in wheat. Euphytica 119:185-190

Snyder RL (1985) Hand calculating degree days. Agric Meteorol 35:353-358

Stephenson TJ, McIntyre CL, Collet C, Xue GP (2007) Genome-wide identification and expression analysis of the NF-Y family of transcription factors in Triticum aestivum. Plant Mol Biol 65:77-92

Suarez-Lopez P, Wheatley K, Robson F, Onouchi H, Valverde F, Coupland G (2001) CONSTANS mediates between the circadian clock and the control of flowering in Arabidopsis. Nature 410:1116-1120

Sun T (2010) Gibberellin-GID1-DELLA: a pivotal regulatory module for plant growth and development. Plant Physiol 154:567-570 
Tang T (2016) Physiological and genetic studies of an alternative semi-dwarfing gene Rht18 in wheat. PhD thesis, University of Tasmania

Thomashow MF (2010) Molecular basis of plant cold acclimation: insights gained from studying the CBF cold response pathway. Plant Physiol 154:571-577

Trethowan RM (2014) Defining a genetic ideotype for crop improvement. Methods Mol Biol 1145:1-20

Trethowan RM, Morgunov A, He ZH, De Pauw R, Crossa J, Warburton $\mathrm{M}$ et al. (2006) The global adaptation of bread wheat at high latitudes. Euphytica 152:303-316

Trevaskis B, Bagnall DJ, Ellis MH, Peacock WJ, Dennis ES (2003) MADS box genes control vernalization-induced flowering in cereals. Proc Natl Acad Sci USA 100:13099-13104

Trevaskis B, Hemming MN, Peacock WJ, Dennis ES (2006) HvVRN2 responds to daylength, whereas HvVRN1 is regulated by vernalization and developmental status. Plant Physiol 140:1397-1405

Trevaskis B, Tadege M, Hemming MN, Peacock WJ, Dennis ES, Sheldon C (2007) Short vegetative phase-like MADS-box genes inhibit floral meristem identity in barley. Plant Physiol 143:225-235

Turner A, Beales J, Faure S, Dunford RP, Laurie DA (2005) The pseudo-response regulator Ppd-H1 provides adaptation to photoperiod in barley. Science 310:1031-1034

Ugarte CC, Trupkin SA, Ghiglione H, Slafer G, Casal JJ (2010) Low red/far-red ratios delay spike and stem growth in wheat. J Exp Bot 61:3151-3162

Waddington SR, Cartwright PM, Wall PC (1983) A quantitative scale of spike initial and pistil development in barley and wheat. Ann Bot 51:119-130

Wang S, Ward RW, Ritchie JT, Fischer RA, Schulthess U (1995) Vernalization in wheat I. A model based on the interchangeability of plant age and vernalization duration. Field Crops Res 41:91-100

Welsh JR, Kein DL, Pirasteh B, Richards RD (1973) Genetic control of photoperiod response in wheat. In: Sears ER, Sears LMS (eds) 4th International Wheat Genetics Symposium, Agricultural Experimental Station: University of Missouri, USA. pp 879-884

Whan BR (1976) Emergence of semidwarf and standard wheats, and its association with coleoptile length. Aust J Exp Agric $16: 411-416$

Wilhelm EP, Boulton MI, Al-Kaff N, Balfourier F, Bordes J, Greenland AJ et al. (2013) Rht-1 and Ppd-D1 associations with height, GA sensitivity, and days to heading in a worldwide bread wheat collection. Theor Appl Genet 126:2233-2243

Wilhelm EP, Turner AS, Laurie DA (2009) Photoperiod insensitive Ppd-A1a mutations in tetraploid wheat (Triticum durum Desf.). Theor Appl Genet 118:285-294

Wilsie CP (1962) Crop adaptation and distribution. W. H. Freeman and Company, London

Würschum T, Langer SM, Longin CFH, Tucker MR, Leiser WL (2017) A modern Green Revolution gene for reduced height in wheat. Plant J 92:892-903
Würschum T, Longin CFH, Hahn V, Tucker MR, Leiser WL (2016) Copy number variations of CBF genes at the Fr-A2 locus are essential components of winter hardiness in wheat. Plant J 89:764-773

Xiao J, Xu SJ, Li CH, Xu YU, Xing LJ, Niu YD et al. (2014) OGlcNAc-mediated interaction between VER2 and TaGRP2 elicits TaVRN1 mRNA accumulation during vernalization in winter wheat. Nat Commun 5:4572

Xie L, Zhang Y, Wang K, Luo X, Xu D, Tian X, et al. (2019) TaVrt2, an SVP-like gene, cooperates with TaVrn1 to regulate vernalization-induced flowering in wheat. New Phytol https://doi. org/10.1111/nph.16339

Xu SJ, Xiao J, Yin F, Guo XY, Xing LJ, Xu YY et al. (2019) The protein modifications of O-GlcNAcylation and phosphorylation mediate vernalization response for flowering in winter wheat. Plant Physiol 180:1436-1449

Yamaguchi-Shinozaki K, Shinozaki K (2006) Transcriptional regulatory networks in cellular responses and tolerance to dehydration and cold stresses. Annu Rev Plant Biol 57:781-803

Yamaguchi S (2008) Gibberellin metabolism and its regulation. Ann Rev Plant Biol 59:225-251

Yan L, Fu D, Li C, Blechl A, Tranquilli G, Bonafede M, Sanchez A et al. (2006) The wheat and barley vernalization gene VRN3 is an orthologue of FT. Proc Natl Acad Sci USA 103:19581-19586

Yan L, Loukoianov A, Tranquilli G, Helguera M, Fahima T, Dubcovsky J (2003) Positional cloning of the wheat vernalization gene VRN1. Proc Natl Acad Sci USA 100:6263-6268

Yan L, Loukoianov A, Blechl A, Tranquilli G, Ramakrishna W, SanMiguel P et al. (2004) The wheat VRN2 gene is a flowering repressor downregulated by vernalization. Science 303:1640-1644

Zadoks JC, Chang TT, Konzak CF (1974) Decimal code for growth stages of cereals. Weed Res 14:415-421

Zalom FG, Goodell P, Wilson L, Barnett WW, Bentley WJ (1983) Degree-days, the calculation and use of heat units in pest management. In: University of California (ed) University of California Division of Agriculture and Natural Resources Leaflet 21373, California, Berkeley

Zeevaart JAD (2006) Florigen coming of age after 70 years. Plant Cell 18:1783-1789

Zhang WP, Zhao GY, Gao LF, Kong XY, Guo ZA, Wu BH et al. (2016) Functional studies of heading date-related gene TaPRR73, a paralog of Ppd1 in common wheat. Front Plant Sci 7:772

Zhao B, Wu TT, Ma SS, Jiang DJ, Bie XM, Sui N et al. (2019) TaD27-B gene controls the tiller number in hexaploid wheat. Plant Biotechnol J 18:513-525

Zikhali M, Wingen LU, Griffiths S (2016) Delimitation of the earliness per se D1 (Eps-D1) flowering gene to a subtelomeric chromosomal deletion in bread wheat (Triticum aestivum). J Exp Bot 67:287-299 